\title{
ANALISA PERLAKUAN AKUNTANSI TERHADAP AKUSISI DAN PENGARUHNYA TERHADAP KINERJA KEUANGAN PERUSAHAAN ( STUDI KASUS PADA PT. JOHNSON \& JOHNSON INDONESIA )
}

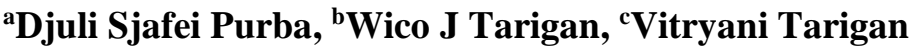 \\ ${ }^{a b c}$ Universitas Simalungun (USI) \\ djulipurba484@gmail.com
}

\begin{abstract}
ABSTRAK
Analisa perlakuan akuntansi terhadap akusisi dan pengaruhnya terhadap kinerja keuangan perusahaan ( Studi Kasus pada PT. Johnson \& Johnson Indonesia ). Tujuan penelitian untuk menganalisa penerapan akuisisi yang tepat dan sesuai perundang undangan dan Standar Akuntansi Keuangan dan bagaimana perkembangan kinerja keuangan perusahaan yang terlibat akuisisi sebelum dan sesudah akuisisi. Dalam kaitannya dalam masalah akuisisi serta pengaruhnya terhadap kinerja keuangan perusahaan yang akan dibahas ini, maka perumusan hipotesa yang dilakukan adalah bahwa perlakuan akuntansi atas akuisisi telah dilakukan menurut Standar Akuntansi Keuangan No.22. Di dalam pengumpulan data data yang dibutuhkan dalam penelitian menggunakan Studi Kepustakaan ( Library Research ), Observasi ( Observation ) dan Metode Analisa yaitu metode Deskiptif dan metode Komparatif. Pelaksanaan akuisisi yang dilakukan oleh Johson \& Johnson terhadap Pfizer dilakukan setelah mendapat persetujuan RULBPS antara pihak - pihak yang berkepentingan, persetujuan dari Badan Koordinasi Penanaman Modal, persetujuan dari pihak lain seperti departemen kehakiman, dan pihak kreditor. Selain itu, Johson \& Johnson juga mengadakan penilaian terhadap perusahaan yang diakuisisi melalui pihak independen. Dengan demikian pelaksanaan akuisisi telah mengikuti aturan pemerintah sebagaimana yang telah ditetapkan segala peraturan nya dalam UU No. 1 tahun 1995 tentang Perusahaan Perseroan Terbatas. Metode penggabungan usaha yang dilakukan untuk akuisisi Johnson \& Johnson terhadap Pfizer adalah metode pembelian. Perusahaan mengalami penurunan kinerja setelah perusahaan mengakuisisi Pfizer. Penurunan kinerja dilihat dari meningkatnya rasio solvabilitas yang tinggi. Karena perusahaan memiliki hutang yang cukup besar hampir seluruh pembiayaan perusahaan dibiayai oleh hutang.
\end{abstract}

Kata Kunci : Akuisisi, Kinerja Keuangan Perusahaan

\section{ABSTRACT}

The purpose of the study is to analyze the application of the right acquisition and in accordance with the legislation and Financial Accounting Standards and how the development of the financial performance of the companies involved in the acquisition before and after the acquisition. In relation to the acquisition problem and its effect on the company's financial performance which will be discussed, the formulation of the hypothesis is that the accounting treatment for the acquisition has been carried out according to Financial Accounting Standard No.22. In collecting data - the data needed in research using Library Research (Library Research), Observation (Observation) and Analysis Methods, namely descriptive methods and comparative methods. The acquisition carried out by Johson \& Johnson of Pfizer was carried out after obtaining RULBPS approval between interested parties, approval from the Investment Coordinating Board, approval from other parties such as the justice department, and creditors. In addition, Johnson \& Johnson also conducts an assessment of the acquired company through an independent party. Thus, the implementation 
of the acquisition has followed government regulations as stipulated in Law no. 1 of 1995 concerning Limited Liability Companies. The merger method used for Johnson \& Johnson's acquisition of Pfizer is the purchase method. The company experienced a decline in performance after the company acquired Pfizer. The decrease in performance can be seen from the increase in the high solvency ratio. Because the company has a fairly large debt, almost all of the company's financing is financed by debt

Keyword : Acquisition, Company Financial Performance

\section{PENDAHULUAN}

Pada masa krisis ekonomi sekarang ini, sangatlah sulit bagi sebuah perusahaan untuk berkembang karena sulitnya dana yang dapat dihimpun untuk mengembangkan usahanya. Perusahaan dalam menjalankan aktifitas bisnisnya mempunyai tujuan yaitu Profitable growth dan Risk diversifications yang dapat melakukan tambahan investasi modal kedalam perusahaannya, tetapi hal ini akan sulit pada masa krisis ini. Oleh karena itu perusahaan lebih cenderung mencapainya secara eksternal yaitu penggabungan usaha (Business Combination).

Penggabungan dua perusahaan terjadi karena dua perusahaan atau lebih membentuk satu organisasi tunggal untuk menjalankan kegiatan usaha. Mekanisme penggabungan usaha dapat dilakukan dalam berbagai bentuk yang berbeda untuk meningkatkan pertumbuhan, kekuatan, dan kesehatan perusahaan. Penggabungan kesatuan - kesatuan usaha ini sering kali dicapai melalui penyatuan bermacam - macam perusahaan menjadi satu unit tunggal yang lebih besar. Penggabungan usaha dapat dibedakan jenisnya seperti peleburan (Merger), Konsolidasi, dan pengambil alihan (akuisisi) baik akuisisi saham maupun harta yang dimiliki perusahaan lain.

Para pemilik perusahaan cenderung memilih alternatif akuisisi dibandingkan dengan penggabungan usaha yang lain. Hal ini didasari oleh karateristik para pemegang saham perusahaan yang cenderung ingin mengendalikan atau memiliki kekuatan dalam pengelolaan bisnis.

Penerapan akuisisi lebih disukai karena tidaklah mudah untuk membangun suatu perusahaan baru yang membutuhkan dana yang besar dan waktu yang lama serta memiliki faktor kegagalan yang cukup tinggi. Selain itu, dengan akuisisi dapat diperoleh suatu organisasi perusahaan yang lebih kuat dan produksi yang lebih serta dapat memperluas daerah pemasaran dan meningkatkan volume penjualan. Bagi perusahaan - perusahaan kecil, akuisisi dapat dijadikan alat untuk memperluas economic of scale atau skala perusahaan yang lebih optimal karena volume perrusahaan dan kapasitas produksinya.

Praktek akuisisi merupakan metode perusahaan untuk mencapai tujuan yang lebih bersifat ekonomis. Hal ini dapat berlangsung atas dasar kerjasama beberapa perusahaan yang bermaksud mengembangkan eksistensinya dengan cara melakukan penggabungan usaha yaitu untuk memperoleh kinerja yang lebih baik dengan mengkosolidasikan laporan keuangannya sehingga penjualan dan laba dapat naik secara mendadak.

Tetapi akuisisi juga dapat menimbulkan kecurigaan karena akuisisi menimbulkan kesan seolah - olah akuisisi tersebut merupakan usaha pemegang saham mayoritas untuk memperoleh dana segar bagi keuntungan pribadi atau kelompok saja. Selain itu, pemegang saham perusahaan yang mengakuisisi juga mempunyai saham diperusahaan yang diakuisisi sehingga membuka peluang untuk merekayasa nilai akuisisi yang merugikan pihak public.

Dalam hal ini yang perlu diperhatikan adalah bahwa para pemegang saham dan calon investor memperoleh informasi yang benar atas rencana penggunaan dana untuk akuisisi. Berkaitan dengan hal tersebut peran profesi penunjang sebagai pihak yang independen yang menentukan nilai perusahaan sangat penting. Diupayakan agar dana dari publik tidak digunakan untuk membeli perusahaan yang terlalu tinggi atau tidak wajar. Apabila dana publik digunakan membeli perusahaan yang tidak sehat maka secara tidak langsung investor ikut memiliki perusahaan yang tidak sehat 
tersebut. Untuk itu nilai wajar dan pelaporan keuangan atas perusahaan sasaran akuisisi itu harus diungkapkan secara terbuka dan kewajarannya dinilai oleh pihak yang independen

Dengan adanya beberapa aspek negatif dari akuisisi maka diperlukan aturan perundang undangan yang mampu menanggulangi praktek bisnis yang merugikan tersebut, yaitu UU No.1 Tahun 1995.tentang undang - undang Perusahaan Perseroan Terbatas (UU PT) yang mengatur masalah merger, konsolidasi, dan akuisisi dalam Bab VII Pasal 102 sampai 109. Undang - Undang No. 8 Tahun 1995 Tentang Pasar Modal Pasal 82 sampai 84, Peraturan BAPEPAM No. IX. G. 1 Tentang Penggabunagn Usaha Perusahaan Publik atau Emiten, dan Perlakuan Akuntansi yang menurut Standar Akuntansi Keuangan yang telah ditetapkan oleh Ikatan Akuntan Indonesia (IAI) agar penerapan akuisisi diperusahaan dilakukan sesuai prosedur yang telah ditetapkan. Selain itu, Undang - Undang No.5 Tahun 1995 tentang larangan praktek monopoli dan persaingan usaha tidak sehat juga mengatur masalah tersebut pada bagian IV pasal 28 sampai pasal 29.

\section{TINJAUAN PUSTAKA}

Menurut Standart Akuntansi Keuangan (PSAK) No.22, Penggabungan usaha adalah Penyatuan dua atau lebih perusahaan yang terpisah menjadi satu entitas ekonomi karena satu perusahaan menyatu dengan ( Uniting with) perusahaan lain atau memperoleh kendali ( Control) atas aktiva dan operasi perusahaan lain. Secara keseluruhan penggabungan usaha itu memuat beberapa unsur pokok yaitu : 1) Terdapat dua atau lebih satuan usaha yang terlibat dalam penggabungan usaha, Terjadi pengambilalihan atau peleburan satuan usaha, Bahwa salah satu perusahaan mendapatkan kendali atas aktiva dan operasi lain dan . Dalam penggabungan usaha terjadi satu entitas ekonomi baru

Penggabungan usaha dibedakan menjdi tiga macam yaitu :

a. Peleburan (merger)

Peleburan terjadi dengan perolehan langsung harta benda satu atau beberapa perusahaan oleh perusahaan lain. Perusahaan yang mengambil alih harta benda perusahaan lain tetap mempertahankan identitasnyaa dan meneruskan operasinya sebagai kesatuan usaha yang lebih besar, perusahaan yang harta bendanya diambil alihkan dibuburkan dan harus melepaskan identitasnya.

Ilustrasi : PT . A + PT. B = PT. A atau PT . B

b. Konsolidasi terjadi apabila sebuah perusahaan diorganisir (didirikan) secara khusus untuk memperoleh aktiva dan menanggung kewajiban dua buah perusahaan atau lebih yang telah ada sebelumnya. Selanjutnya sebuah perusahaan baru berdiri dan perusahaan - perusahaan yang ada sebelumnya dibubarkan.

Ilustrasi : PT . A + PT. B = PT . C

c. Akuisisi

Akuisisi terjadi apabila suatu perusahaan memperoleh aktiva produktif dari entitas usaha lain dan mengintegrasikan aktiva - aktiva tersebut kedalam operasi miliknya. Penggabungan usaha juga mengacu kepada akuisisi ketika suatu perusahaan memperoleh pengendalian operasi atas fasilitas produktif entitas lain dengan memiliki sejumlah besar ( mayoritas ) saham berhak suara yang beredar. Perusahaan yang diakuisisi tidak perlu dibubarkan, tetapi perusahaan tersebut tetap mempunyai eksistensi lagi.

Ilustrasi : PT. A + PT. B = PT. A atau PT. B

\section{Akuisisi}

Istilah akuisisi sering digunakan untuk mengukapkan pengambilalihan kendali dari satu perusahaan terhadap perusahaan lainnya sedangkan istilah merger dan kosolidasi masing - masing mengungkapkan penggabungan usaha dimana perusahaan yang diakuisisi tersebut telah dibubarkan dan perusahaan yang bergabung menbentuk perusahaan baru. Dewasa ini, praktek akuisisi telah banyak dilakukan oleh pengusaha Indonesia dalam rangka restrukturisasi terutama dilakukan pada perseroan terbatas. Akuisisi merupakan cara mengembangkan perusahaan yang sudah ada atau menyelamatkan perusahaan yang sedang mengalami kesulitan dana. Dengan dilakukannya ptraktek 
akuisisi diharapkan dapat memperoleh keuntungan - keuntungan di berbagai bidang seperti meningkatkan kapasitas pemasaran, kapasitas produksi, mengurangi jumlah pasaing, menebarkan resiko, dan lain - lainnya.

Menurut USAP Review, "Akuisisi adalah pengambil alihan suatu perusahaan dengan memperoleh kendali atas aktiva netto dan operasi perusahaan lain melalui pemilikan sebagian besar sahamnya yang beredar dan perusahaan yang diambil alih tidak dibubarkan atau tetap eksis. (Ikatan Akuntan Indonesia, 2016).

Menurut UU No.1 tahun 1995 tentang Undang - Undang Perseroan Terbatas pasal 103, istilah yang dipakai adalah pengambilalihan perseroan yaitu : Pengambilalihan atas seluruh atau sebagian besar saham yang berakibat beralihnya pengendalian atau perseroan yang diambil alih kepada pihak yang mengambil alih, sedangkan akuisisi aset yaitu mengenai tindakan hukum perseroan yang berupa pengalihan atau menjadikan jaminan hutang seluruh atau sebagian besar kekayaan perseroan kepada pihak lain (Azizah, 2016).

Menurut Pernyataan Standar Akuntansi Keuangan No.22, suatu akuisisi terjadi bila salah satu perusahaan memperoleh kendali atas perusahaan lain yang diasumsikan terjadi apabila salah satu perusahaan yang bergabung memperoleh lebih dari $50 \%$ hak suara pada perusahaan lain, kecuali apabila dapat dibuktikan bahwa tidak terdapat pengendalian walaupun kepemilikan lebih dari $50 \%$. Meskipun salah satu perusahaan yang tergabung tidak memiliki lebih dari $50 \%$ hak suara pada perusahaan lain, perusahaan pengakuisisi mungkin tetap dapat diidentifikasi apabila salah satu perusahaan yang tergabung memperoleh kekuasaan (Power) lebih dari $50 \%$ hak suara atas perusahaan yang lain tersebut berdasarkan perjanjian dengan investor lain, kekuasaan (power) untuk mengatur kebijakan keuangan dan operasi perusahaan lain tersebut berdasarkan anggaran atau perjanjian, kekuasaan ( Power ) untuk mengangkat dan memberhentikan sebagian besar anggota pengurus perusahaan yang lain tersebut dan kekuasaan (Power) untuk mendapatkan hak suara mayoritas dalam rapat direksi perusahaan yang lain tersebut

Adapun tujuan perusahaan dalam melakukan akuisisi adalah :

1. Memperbesar usaha dengan biaya yang murah

Suatu perusahaan yang sudah berjalan tidak perlu masuk ke dalam bidang usaha yang baru (diversifikasi) atau mengembangkan usaha yang sudah ada (ekspansi), dengan memulainya dari nol atau secara bertahap dengan dana yang cukup besar tetapi dapat langsung memasuki suatu usaha dalam skala yang besar dengan biaya yang relative murah.

2. Memperbaiki sistem manajemen perusahaan terakuisisi

Perusahaan yang lemah menajemen akan sulit berkembang secara operasional walaupun mempunyai dana yang cukup. Perusahaan yang demikian tidak mampu bersaing dengan perusahaan lain terutama yang sejenis dan tidak mustahil akan mengalami kehancuran. Salah satu cara penyelamatannya adalah bergabung dengan kelompok konglomerasi yang berpengalaman baik dalam segi manajemen.

3. Mengurangi atau menghambat persaingan

Jumlah perusahaan yang bersaing dikurangi karena policy dipegang oleh satu kelompok perusahaan atau oleh perusahaan besar pengakuisisi.

4. Mempertahankan kontinuitas bisnis

Yaitu dengan mengakuisisi perusahaan lain atau jenis uasaha yang ada dalam mata rantai bisnisnya sehingga akan memudahkan control atas jalur usaha yang ditempuhnya

5. Pembagian risiko bisnis

Pembagian risiko terhadap suatu jenis perusahaan tertentu yang mengalami kemunduran dan beberapa perusahaan lain yang tetap sehat.

Ditinjau dari segi kekuasaan perseroan akuisisi dibedakan menjadi dua yaitu :

1. Akuisisi Internal yaitu akuisisi terhadap perseroan dalam kelompok atau grup sendiri. Dalam hal ini suatu kelompok atau grup memiliki beberapa perseroan baik sejenis maupun tidak sejenis yang berdiri sendiri. 
2. Akuisisi Eksternal yaitu akuisisi terhadap perseroan diluar kelompok atau grup sendiri atau terhadap perseroan dari kelompok lain, baik sejenis atau tidak sejenis dengan alasan seperti tersebut diatas. Akuisisi dapat menyelamatkan perseroan terakuisisi dan sebaliknya memperkuat daya saingnya dan menciptakan monopoli

Menurut (Marcel, 2002), Akuisisi ditinjau dari keberadaan perseroan dapat dibedakan menjadi dua jenis. Pemilihan antara kedua jenis ini adalah sangat penting karena dapat memberikan gambaran yang jelas tentang latar belakang dan tujuan akuisisi. Akuisisi sering dipersepsikan sebagai tindakan negative yaitu penipuan ( bad trick ) dari perusahaan. Tetapi pendapat tersebut tidaklah benar karena tindakan akuisisi dapat berdampak positif seperti peningkatan produktivitas riil dan penciptaan sinergi. Kedua jenis akuisisi tersebut adalah :

a. Akuisisi Finansial

Akuisisi financial merupakan suatu tindakan akuisisi terhadap satu atau beberapa perusahaan untuk mencapai keuntungan financial dengan jalan memperbaiki kondisi - kondisi perusahaan perusahaan terakuisisi. Perseroan terakuisisi biasanya daam posisi merugi, beban hutang membesar, distribusi, dan pemasaran produksi tidak lancar, serta harga saham di bursa efek menurun. Dalam hal ini perseroan terakuisisi mengalami kesulitan dana. Setelah perseroan terakuisisi itu menjadi sehat, sahamnya dijual kepada pihak lain dengan harapan memperoleh keuntungna financial. Dengan demikian akuisisi financial adalah membeli perusahaan target dengan harga semurah mungkin untuk menjual kembali dengan harga yang lebih tinggi. Namun demikian apabila transaksi tersebut dilaksanakan antar perusahaan yang berada dalam satu gup bisnis atau kepemilikan yang sama, harga beli dapat menjadi mahal atau lebih murah, tergantung pada kepentingan dan keuntungan yang akan diperoleh pemilik mayoritas tersebut.

b. Akuisisi Strategis

Akuisisi strategis merupakan suatu akuisisi yang dilaksanakan dengan tujuan untuk mecipakan sienergi dengan didasarkan pada pertimbangan - pertimbangan jangka panjang. Sienergi ini tidak hanya berupa sinergi financial tetapi juga mencakup sinergi produksi, sinergi distribusi, sinergi pengembangan, teknologi, dan gabungan dari sinergi - sinergi tersebut. Sebagai ilustrasi adalah sinergi yang diciptakan dalam produksi dan pemasaran, yakni antara perusahaan yang menghasilkan produk tertentu (produsen) dengan perusahaan yang mendistribusikan produk tersebut (distributor). Di satu pihak produsen memiliki keunggulan teknik produksi namun tidak memiliki keunggulan dalam distribusian produk karena mempunyai jaringan distribusi yang luas akan tetapi tidak memiliki kemampuan teknik produksi. Dalam rangka mewujudkan sinergi usaha maka perusahaan pertama mengakuisisi perusahaan kedua sehingga dapat menutup kelemahan kelemahan mereka sekaligus meningkatkan penjualan dan menampilkan kekuatan yang lebih besar.

\section{Ilustrasi : Synergy $=V a b-(V a+V b)$}

Nilai perusahaan A adalah Va dan penjumlahan nilai masing - masing perusahaan yang bergabung adalah sinergi dari akuisisi. Sinergi ini mencerminkan penggabungan dua faktor yang menghasilkan keuntungan lebih besar dibandingkan dengan jumlah keuntungan yang dihasilkan apabila masing - masing perusahaan tersebut bekerja sendiri. Aktivitas merger dan akuisisi dilakukan perusahaan dengan harapan mendatangkan keuntungan dan peningkatan kinerja perusahaan. Kondisi saling menguntungkan akan terjadi apabila kegiatan merger dan akuisisi tersebut memperoleh sinergi. Sinergi yang dihasilkan dari aktivitas merger dan akuisisi diharapkan dapat meningkatkan kinerja keuangan perusahaan.(Resmilia, Hardiyanto, \& Ilmiyono, 2018).

Menurut Pokok - Pokok Perseroan Terbatas Tahun 1995 sebelum melakukan tindakan akuisisi perlu mengevaluasi secara mendalam mengenai hal - hal berikut : 1) Manajemen, kemanpuan manajemen dalam mengelola perusahaan terutama pada masa pasca akuisisi dianggap sangat penting. Dalam mempersiapkan pasca akuisisi tugas yang dikerjakan manajemen akan bertambah dan antisipasi ke arah sana akan sangat bermanfaat bila sejak awal sudah direncanakan secara matang, 2) Team / Komite yang berspesialisasi dalam melakukan akuisisi, Pembentukan team yang berspesialisasi dalam 
melakukan akuisisi akan membantu terutama bila manajemen memberikan waktu dan resources bagi team tersebut, 3) Penasehat / Konsutan Independen, Penasehat profesioanal merupakan hal yang sangat mutlak diperlukan mengingat pengalaman professional yang dimilikinya serta kemampuan untuk berkomunikasi dengan banyak pihak yang terkait dengan team akuisisi. Kebutuhan penasehat sangat menentukan untuk membantu fairness dan disclosure yang diharapkan, 4) Alasan rasional dilakukan akuisisi, Akuisisi yang baik senantiasa memiliki alasan bisnis yang tepat dan akurat bukan hanya semata - mata karena adanya suatu penawaran atau attractive deal. Nilai tambah (value-added) harus senantiasa mendasari adanya akuisisi. Tugas perusahaan pengakuisisi yaitu mengusahakan adanya upaya penambahan nilai tambah yang pada akhirnya juga meratakan manfaat pemegang saham, 5) Rencana pasca akuisisi, Rencana pasca akuisisi yang baik dan cukup rinci sangat dibutuhkan, terutama menjelang perdagangan bebas di mana kekuatan perdagangan juga harus disejajarkan dengan kekuatan untuk melakukan investasi sehingga diperlukan manajemen dengan kemampuan wirausaha yang cukup tinggi dan 6) Pendanaan, Faktor penentu yang ikut berperan dalam akuisisi adalah pendanaan. Dengan pendanaan yang cukup diusahakan suatu konsistensi usaha untuk masa pasca akuisisi (Kansil, 2005)

Akuisisi harus dirancang sebagai proses dinamis. Program akuisisi yang sukses harus termasuk dalam rencana strategi perusahaan seperti diversifikasi, ekspansi produk, dan akses terhadap teknologi. Suatu proses akuisisi biasanya diawali dengan perusahaan yang dalam hal ini mengakuisisi dan perusahaan yang diakuisisi oleh perusaha pengakuisisi. Ada beberapa cara yang dapat dilakukan agar poses akuisisi dapat mencapai targetnya, diantaranya melalui tender offers dan takeovers. Tender offers atau penawaran tender merupakan cara kesepakatan yang dilakukan oleh perusahaan yang mengakuisisi dengan jalan mengajukan penawaran kepada pemegang saham perusahaan yang akan diambil alih. Takeovers yaitu proses akuisisi oleh suatu perusahaan bila mana perusahaan yang akan diakuisisi tidak setuju dengan adanya penggabungan. Takeovers dilakukan setelah perusahaan yang akan mengakuisisi perusahaan lainnya mengalami kegagalan karena adanya penolakan oleh direksi perusahaan yang akan diakuisisi.

Pernyataan Standar Akuntansi Keuangan (PSAK) No. 22 mengatur perlakuan akuntansi untuk penggabungan usaha (business combination ) dapat berupa suatu akuisisi (acquisition) dan penyatuan kepemilikan (uniting/pooling of interest) baik yang dilakukan melalui perolehan saham maupun aktiva neto. Oleh karena itu, metode akuntansi yang berbeda digunakan untuk masing-masing jenis penggabungan usaha. APB (Accounting Principles Board) No.16, "Business Combination" memberikan dua belas syarat agar transaksi memenuhi persyaratan sebagai penyatuan kepemilikan jika satu syarat tidak terpenuhi maka transaksi tersebut merupakan akuisisi. PSAK No.22 Mensyaratkan bahwa suatu penggabungan usaha diperlakukan sebagai penyatuan kepemilikan bila para pemegang saham perusahaan - perusahaan yang bergabung tidak ada yang lebih dominan dari yang lain setelah terjadi penggabungan usaha dan mereka bersama - sama mengendalikan seluruh atau secara efektif seluruh aktiva neto dan operasi serta bersama-sama berbagi risiko dan manfaat atas perusahaan gabungan tersebut. Walaupun kelihatannya jauh lebih sederhana, sebenarnya PSAK No.22 membawa dampak yang sama dengan APB No. 16, yaitu sulit untuk memenuhi persyaratan penyatuan kepemilikan.

\section{Kinerja Keuangan}

Pengertian kinerja menurut Kamus Besar bahasa Indonesia adalah sesuatu yang dicapai prestasi yang diperlihatkan atau kemampuan kerja. Kinerja keuangan perusahaan adalah hasil kerja yang dilakukan oleh perusahaan dalam aktivitasnya untuk berprestasi dalam mencapai tujuan perusahaan. Selain itu, kinerja perusahaan biasa dilihat dari kemampuan perusahaan tersebut beroperasi secara efesien dan efektif untuk menghasilkan laba yang optimal. Kinerja keuangan perusahaan dapat dilihat dari analisa laporan keuangan yaitu dengan menggunakan analisa rasio. (Kasmir, 2015)

Menurut (Munawir, 2010) Analisa rasio adalah suatu metode analisa untuk mengetahui hubungan dari pos - pos tertentu dalam neraca atau laporan rugi laba secara individu atau kemampuan 
dari kedua laporan tersebut. Menurut (Harahap, 2015) "rasio keuangan adalah angka yang diperoleh dari hasil perbandingan dari satu pos laporan keuangan dengan pos lainnya yang mempunyai hubungan yang relevan dan signifikan.

Menurut (Ashari, 2018) Rasio Solvabilitas adalah "rasio untuk mengetahui kemampuan perusahaan dalam membayar kewajiban jika perusahaan tersebut dilikuidasi. Menurut (Rodoni, 2014), rasio manajemen aktiva mengukur efektivitas perusahaan dalam mengelola aktivanya, yaitu mengukur kemampuan seluruh aktivanya dalam menghasilkan penjualan. Menurut (Brigham, F, \& Houston, 2011), Rasio probabilitas adalah hasil akhir dari sejumlah kebijakan dan keputusan yang dilakukan oleh perusahaan. Rasio - rasio yang dibahas sejauh ini dapat memberikan petunjuk-petunjuk yang berguna dalam menilai keefektifan dari operasi sebuah perusahaan, tetapi rasio probabilitas akan menunjukkan kombinasi efek dari likuiditas, manajemen aktiva, dan utang-utang pada hasil operasi.

\section{METODE PENELITIAN}

Didalam pengumpulan data - data yang dibutuhkan dalam penelitian ini menggunakan tehnik pengumpulan data sebagai berikut :

a. Studi Kepustakaan ( Library Research ), yaitu penelitian yang akan dilakukan dengan mempelajari buku - buku dan bahan - bahan tertulis lainnya seperti : Literatur - literatur, majalah - majalah dan jurnal yang berhubungan dengan pembahasan masalah pokok penelitian. Metode ini bertujuan untuk mendapatkan dasar teoritis yang dipakai untuk pembahasan masalah yang sedang diteliti. Dengan riset pustaka ini penulis berharap dapat membandingkan keterangan - keterangan yang dipeoleh dengan kenyataan yang ada dalam praktek.

b. Observasi ( Observation ), Observasi yang dilakukan penulsi adalah dengan melihat dan menilai secara lansung dilapangan. Penelitian langsung ini dilakukan dengan cara wawancara dengan orang - orang yang terlibat secara langsung dengan masalah yang dibahas

c. Metode Analisa

Metode analisa yang dilakukan penulis adalah sebagai berikut :

a. Metode Deskiptif yaitu suatu metode dimana data itu dikumpulkan disusun dan digolongkan, kemudian dianlisa sehingga memberikan keterangan yang terungkap bagi pemecahan masalah yang dihadapi.

b. Metode Komparatif yaitu suatu metode dimana teori - teori yang ada dibandingkan dengan praktek didalam perusahaan kemudian diambil kesimpulan yang selanjutnya diberi saran dari hasil perbandingan tersebut.

\section{HASIL}

\section{Penilaian Terhadap Perusahaan yang Diakuisisi}

Johnson \& Johnson menunjuk CIBA (Center for Investment And Bussiness Advisory) untuk menilai usah PT. Pfizer Indonesia, dan Satyatama Graha Tara (SGT) untuk menilai aktiva tetap Pfizer. Dalam penilaiannya, CIBA menggunakan metode nilai buku yang disesuikan (adjusted flow). Berdasarkan perhitungannya, kisaran nilai usaha (corporate value) Pfizer dihitung dengan metodemetode diatas adalah sebagai berikut :

a. Nilai usaha Pfizer senilai Rp. 1.753 miliar menurut metode pendekatan biaya.

b. Nilai usaha Pfizer senilai Rp.1.876 miliar menurut metode pendekatan nilai tunai arus kas

Berdasarkan hal - hal tersebut diatas maka dapat disimpulkan bahwa nilai usaha Pfizer 2001 berkisar antara Rp. 1.753 miliar dan Rp. 1.876 miliar. Metode adjusted book value dibuat berdasarkan nilai buku sebagaimana disebut dalam laporan keuangan Pfizer yang disusun oleh Satyatama Graha Tara. Metode discounted cash flow dibuat berdasarkan penjumlahan nilai sekarang dari arus kas bersih hasil operasi dalam suatu periode tertentu dan nilai akhir (terminal value) periode tersebut. Satyatama Graha Tara melakukan penilaian atas kekayaan milik Pfizer, berupa harta 
kekayaan berwujud (tangible assets) yang terdiri atas tanah, kendaraan bermotor, kapal dan fixtures serta furniture. SGT menilai semua kekayaan milik Pfizer berdasarkan Nilai Sehat (Healthy Value) kecuali tanah yang menggunakan Nilai pasar wajar (fair market value)

Dalam hal ini nilai pasar yang baik dipakai merupakan nilai tertinggi dari sesuatu apabila diperjual di pasaran bebas dengan memberi waktu untuk memperoleh pembeli yang mengenal benar tentang segala kegunaan barang yang dipasarkan. Untuk mendapatkan nilai pasar wajar digunakan metode Market Data approach yaitu metode yang didasarkan atas pemasaran yang dilakukan, pencatatan - pencatatan, interview dengan narasumber, dan pemilik tanah lainnya yang kira - kira sebanding kondisinya dengan Pfizer. Selain itu juga diperhatikan faktor - faktor seperti lokasi,ukuran, bentuk, kemudahan dan unsur waktu.

Nilai sehat menurut SGT adalah jumlah biaya yang diperlukan untuk membuat atau mengganti baru (cost reproduction / replacement new) aktiva yang nilai, setelah dikurangi penyusutan, berdasarkan kondisi saat itu. Di bandingkan dengan unit sejenis dan diasumsikan bahwa unit itu akan terus dipergunakan sesuai dengan kegunaannya. cost reproduction/ replacement new adalah jumlah yang dibutuhkan untuk membayar atau memperoleh satu unit yang hampir sama atau ekuivalen dengan obyek Pfizer yang dinilai, baik mengenai bahan, ukuran, bentuk, desain, fungsi, berdasarkan harga yang berlaku pada saat penilaian dilakukan

\section{Perlakuan Akuntansi untuk Transaksi Akuisisi}

Johnson \& Johnson mengakuisisi seluruh aktiva dan usaha pembuatan obat bebas milik Pfizer setelah memperhatikan faktor - faktor seperti usaha,aktiva,pasiva Pfizer. Kemampuan menghasilkan laba, dan kinerja keuangan Pfizer. Tanggal efektif akuisisi Pfizer oleh Johnson \& Johnson adalah 1 Mei 2002. Sejak tanggal tersebut Johnson \& Johnson mempunyai wewenang untuk mengatur kebijakan keuangan dan operasi suatu perusahaan untuk mendapatkan manfaat dan kegiatannya.

\section{a. Perlakuan Akuntansi Sesuai PSAK No.22 tentang Penggabungan Usaha}

Penggabungan Usaha membedakan perlakuan akuntansi sebagai akuisisi dan penyatuan kepemilikan. Transaksi Johnson \& Johnson terhadap Pfizer diindentifikasikan sebagai akuisisi sehingga dicatat dengan metode pembelian karena perusahaan mempunyai kuasa penuh atas aktiva tertentu dan operasi Pfizer dengan memberikan data pencatatan aktiva tetap dan mengakui suatu pembiayaan dimana kepemilikan Johnson \& Johnson terhadap Pfizer adalah kepemilikan $100 \%$.

\section{b. Analisa Transaksi Akuisisi}

Johnson \& Johnson membeli seluruh usaha dan aktiva neto Pfizer dengan harga gross sebesar Rp.1.886 miliar sedangkan harga pembelian neto sebesar Rp 1.429 miliar. Dalam perjanjian jual beli diuraikan harga pembelian tersebut sebagai berikut :

1. Untuk aktiva tetap sebesar Rp. 1.525 miliar dengan pembayaran yang akan diperhitungkan dengan mengambil alih pasiva Pfizer per tanggal 30 April 2002 yang nilai bukunya sebesar Rp. 450 miliar.

2. Untuk aktiva lancar yang nilai bukunya per 30 April 2002 sebesar Rp 119 miliar.

3. Untuk aktiva dalam penyelesaian dan aktiva lain-lain yang nilai bukunya per 30 April 2002 sebesarr Rp. 142 miliar

Cara pembayarannya akan dilakukan dengan cara :

1. Pengambil alihan kewajiban jangka pendek dan hutang bank Pfizer dengan nilai buku sekitar sebesar Rp 457 miliar per 30 mei 2002.

2. Penerbitan wesel bayar tanpa bunga dengan jangka waktu satu tahun sebesar sekitar Rp 140 miliar yang akan jatuh tempo pada tanggal 30 mei 2003

3. Pembayaran tunai dengan kas sebesar sekitar Rp. 1.289 miliar yang akan dibayarkan pada tanggal 30 Juni 2002

Akibat hal itu maka Johnson \& Johnson akan membutuhkan dana sebesar Rp.1.289 miliar untuk melakukan pembayaran tunai kepada Pfizer dan sekitar Rp.5.000.000.000,00 untuk membayar biaya lain sehubungan dengan akuisisi. Johnson \& Johnson memperoleh dana tersebut dari pinjaman 
dengan syarat dan kondisi yang berlaku umum dipasar dari beberapa kreditur, termasuk BCA. Pinjaman tersebut diberikan dalam mata uang Rupiah dan dollar US. Setelah akuisisi, Johnson \& Johnson akan mempertimbangkan beberapa alternative untuk mengganti seluruh pinjaman tersebut.

\section{Pengaruh Akuisisi Terhadap Kinerja Perusahaan}

Dalam mengukur kinerja keuangan perusahaan Johnson \& Jonhson, menggunakan rasio keuangan Johnson \& Johnson yang dibandingkan setiap tahunnya dengan menggunakan laporan keuangan yang meliputi neraca dan laporan laba rugi tahun 2000 sampai 2004. Pengukuran kinerja yang diperbandingkan adalah kinerja perusahaan pengakuisisi sebelum dan sesudah akuisisi dimana akuisisi terjadi pada tahun 2002. Laporan keuangan P.T Johnson \& Johnson telah diaudit oleh kantor Akuntan Publik Presetio,Utomo \& Rekan, dengan pendapat wajar tanpa pengecualian untuk setiap tahun yang dianalisa, yaitu tahun 2000 sampai 2004. Perhitungan rasio keuangan P.T Johnson \& Johnson dan persentase penurunan atau kenaikan rasio per tahun yang dibandingkan dengan tahun sebelumnya. Adapun hasil perhitungan rasio PT Johnson \& Johnson adalah sebagai berikut :

Tabel 4.1

Rasio Keuangan PT. Johnson \& Johnson

\begin{tabular}{|c|c|c|c|c|c|}
\hline & \multicolumn{2}{|c|}{ Sebelum akuisisi } & \multicolumn{3}{|c|}{ Setelah Akuisisi } \\
\hline & 2000 & 2001 & 2002 & 2003 & 2004 \\
\hline $\begin{array}{l}\text { Rasio Likuiditas } \\
\text { Current ratio } \\
\text { Quick Ratio }\end{array}$ & $\begin{array}{l}53,08 \% \\
43,73 \%\end{array}$ & $\begin{array}{l}333,92 \% \\
271,35 \%\end{array}$ & $\begin{array}{l}145 \% \\
96,81 \%\end{array}$ & $\begin{array}{l}167,88 \% \\
122,33 \%\end{array}$ & $\begin{array}{l}139,96 \% \\
110,99 \%\end{array}$ \\
\hline $\begin{array}{l}\text { Rasio Solvabilitas } \\
\text { DAR } \\
\text { DER } \\
\text { EM }\end{array}$ & $\begin{array}{l}80,98 \% \\
438,6 \% \\
57,99 \%\end{array}$ & $\begin{array}{l}20,63 \% \\
261,55 \% \\
75,26 \%\end{array}$ & $\begin{array}{l}60,99 \% \\
164,30 \% \\
112,25 \%\end{array}$ & $\begin{array}{l}55,29 \% \\
185,12 \% \\
117,93 \%\end{array}$ & $\begin{array}{l}90,96 \% \\
1481,38 \% \\
1029,61 \%\end{array}$ \\
\hline $\begin{array}{l}\text { Rasio Aktivitas } \\
\text { Total Asset Tumover } \\
\text { Inventory TurnOver }\end{array}$ & $\begin{array}{l}1,57 \mathrm{x} \\
25,30 \mathrm{x}\end{array}$ & $\begin{array}{l}0,94 \mathrm{x} \\
9,44 \mathrm{x}\end{array}$ & $\begin{array}{l}0,56 x \\
5,94 x\end{array}$ & $\begin{array}{l}0,76 x \\
6,78 x\end{array}$ & $\begin{array}{l}0,66 \mathrm{x} \\
6,1 \mathrm{x}\end{array}$ \\
\hline $\begin{array}{l}\text { Rasio Profitabilitas I } \\
\text { Margin Ratio } \\
\text { Return on Investmetn } \\
\text { Return on Equity } \\
\text { Earning per Share }\end{array}$ & $\begin{array}{l}6.26 \% \\
11,38 \% \\
72,83 \% \\
\text { Rp } 59,041\end{array}$ & $\begin{array}{l}16,39 \% \\
20,43 \% \\
35,3 \% \\
\operatorname{Rp} 288\end{array}$ & $\begin{array}{l}14,6 \% \\
11,88 \% \\
24,55 \% \\
\operatorname{Rp} 400\end{array}$ & $\begin{array}{l}12,56 \% \\
11,51 \% \\
35,12 \% \\
\operatorname{Rp} 350\end{array}$ & $\begin{array}{l}-19,24 \% \\
-14,83 \% \\
-92,88 \% \\
(\operatorname{Rp} 545)\end{array}$ \\
\hline $\begin{array}{l}\text { Rasio profitabilitas II } \\
\text { Margin Ratio } \\
\text { Return on Investment } \\
\text { Return on Equity } \\
\text { Earning per share }\end{array}$ & $\begin{array}{l}6,26 \% \\
11,83 \% \\
72,83 \% \\
\operatorname{Rp} 59,041\end{array}$ & $\begin{array}{l}16,39 \% \\
20,45 \% \\
35,39 \% \\
\operatorname{Rp} 288\end{array}$ & $\begin{array}{l}14,6 \% \\
11,88 \% \\
24,55 \% \\
\operatorname{Rp} 400\end{array}$ & $\begin{array}{l}12,56 \% \\
11,51 \% \\
35,12 \% \\
\operatorname{Rp} 350\end{array}$ & $\begin{array}{l}9,61 \% \\
7,41 \% \\
46,39 \% \\
\operatorname{Rp} 27\end{array}$ \\
\hline
\end{tabular}

\section{a. Rasio Likuiditas}

Sumber : PT Johnson \& Johnson Indonesia

Rasio Likuiditas bertujuan untuk mengukur kemampuan perusahaan dalam memenuhi kewajiban jangka pendek dengan aktiva lancar yang dimiliki oleh perusahaan dengan tanpa persediaan. Rasio ini terdiri atas rasio lancar (current ratio) dan rasio cepat (quick ratio). Rasio lancar perusahaan sebelum akuisisi menunjukkan tingkat likuiditas yang cukup baik terutama pada tahun 2001 terjadi kenaikan sebesar 529,13\% dari tahun 2000. Pada tahun 2002 saat akuisisi, rasio lancar menunjukan angka $145 \%$, ini berarti bahwa jumlah aktiva lancar ada 1,45 kali dari hutang lancar atau setiap Rp 1,00 hutang lancar dijamin oleh Rp 1,45 aktiva lancar. Dilihat pada tabel diatas 2003 rasio lancer perusahaan kembali mengalami kenaikan dari tahun sebelumnya yaitu sebesar $15,78 \%$. Tetapi, di tahun 2004 mengalami penurunan sebesar 16,63\%.

Seperti halnya dengan rasio lancar, rasio cepat mengalami fluktuasi yang sama. Rasio cepat lebih menunjukkan tingkat likuiditas yang lebih tinggi karena tidak dimasukkannya persediaan yang membutuhkan waktu untuk menjadi uang yang akan dipakai sebagai jaminan hutang. Sebelum akuisisi, rasio cepat naik pada tahun 2001 dari tahun sebelumnya yaitu sebesar 520,47 \%. Pada tahun akuisisi rasio cepat cukup baik yaitu sebesar 96,81\% dan kemudian mengalami penurunan sebesar 9,36\% menjadi sebesar 110,89\%. Rasio ditahun ini menunjukkan angka 88,29\% yang berarti setiap hutang lancar Rp 1,00 dijamin oleh Rp 0,88 aktiva lancar yang lebih likuid. 


\section{b. Rasio Solvabilitas}

Rasio ini menunjukkan kemampuan perusahaan untuk memenuhi kewajiban keuangannya apabila perusahaan dilikuidasi. Rasio ini terdiri atas tiga macam, yaitu rasio kewajiban terhadap aktiva, kewajiban terhadap ekuitas, dan kewajiban jangka panjang terhadap ekuitas. Rasio kewajiban terhadap aktiva sebelum akuisisi menunjukkan tingkat solvabilitas yang cukup baik. Pada tahun 2001 tingkat rasio kewajiban terhadap aktiva hanya sebesar $20,63 \%$ dan mengalami penurunan dari tahun sebelumnya sebesar 74,53\%. Ini berarti bahwa $21 \%$ dari aktiva keseluruhan digunakan untuk menjamin kewajiban. Sesudah akuisisi rasio ini mengalami kenaikan. Pada tahun 2002 rasio ini sebesar 60,99\% kemudian turun kembali menjadi 55,29\% pada tahun 2003, tetapi pada tahun 2004 mengalami kenaikan menjadi 90,96 \%. Hal ini menunjukkan bahwa para kreditorlah yang menyediakan hamper seluruh pembiayaan perusahaan.

Rasio kewajiban terhadap ekuitas sebelum akuisisi menunjukkan angka yang baik karena rasio ini tiap tahun menurun. Pada tahun 2000 rasio ini sebesar 428,6 \% kemudian turun menjadi 261,55\% pada tahun 2001. Pada tahun 2002 sesudah akuisisi rasio ini mencapai titik terendah yaitu sebesar 164,3\% hal ini berarti setiap Rp 1,00 ekuitas dijamin untuk Rp 1,64 kewajiban. Pada tahun berikutnya 2004, rasio ini mengalami peningkatan tajam karena besarnya hutang jangka bank jangka pendek yang harus dibayar yang sebagian besar berasal dari pinjaman untuk pembayaran akuisisi. Rasio ditahun 2004 menunjukkan angka 1481,38 \% yang berarti bahwa setiap Rp 1,00 ekuitas digunakan untuk menjamin Rp 14,81 hutang.

Sama seperti rasio kewajiban terhadap ekuitas, rasio kewajiban jangka panjang terhadap ekuitas setiap tahun sebelum dan sesudah akuisisi mengalami kenaikan terus menerus. Hal ini menunjukkan tingkat solvabilitas yang kurang baik sebelum akuisisi. Pada tahun 2002 rasio ini meningkat sebesar 49,15\% dari tahun sebelumnya. Pada tahun 2003 terjadi peningkatan tajam yaitu sebesar 773,06 \% sehingga rasionya menjadi 1029,61\%. Hal ini berarti setiap Rp 1,00 ekuitas digunakan untuk menjamin Rp 10,29 kewajiban jangka Panjang

\section{c. Rasio Aktivitas}

Untuk mengukur efisiensi perusahaan dalam penggunaan aktivanya digunakan rasio aktivitas. Rasio aktivitas ini terdiri atas perputaran aktiva dan persediaan. Perputaran aktiva sebelum akuisisi menunjukkan tingkat aktiva yang kurang baik. Hal ini ditunjukkan dengan adanya penurunan perputaran aktiva dari tahun 2000 sebesar 1.57 kali menjadi 0,94 kali pada tahun 2001. Perputaran aktiva mencapai titik terendah pada tahun 2002 yaitu sebesar 0,56 kali. Pada saat sesudah akuisisi, perputaran aktiva mulai menunjukkan kenaikan yaitu pada tahun 2003 menjadi 0,75 kali kemudian turun kembali menjadi 0,66 kali. Hasil ini menunjukkan adanya dana yang tersimpan pada keseluruhan aktiva rata - rata hanya berputar 0,83 kali dalam setahun. Ini menunjukkan tingkat perputaran aktiva yang tidak baik.

Lain halnya dengan perputaran aktiva, perputaran persediaan sebelum akuisisi dapat dilihat nilai cukup baik meskipun rasio ini mengalami tingkat penurunan cukup besar pada tahun 2001 yaitu sebesar 62,67\%. Rasio di tahun 2001 menunjukkan angka 9,44 kali. Hal ini berarti dana yang tertanam dalam persediaan berputar rata-rata 9,44 kali dalam setahun. Pada saat sesudah akuisisi, rasio ini mengalami penurunan sebesar 37,08 \% ditahun 2002. Di tahun 2003 rasio aktivitas menunjukan kenaikan sedikit yaitu hanya sebesar 14,14\%. Rasio ini kembali mengalami penurunan di tahun 2004 menjadi 6,1 kali. Penurunan rasio ini menunjukan dana tersimpan pada persediaan berputar rata - rata 6,1 kali dalam setahun.

\section{d. Rasio Profitabilitas}

Rasio ini berguna menilai kemampuan perusahaan. Rasio ini terdiri atas rasio laba bersih terhadap penjualan, pengembalain investasi, pengembalian ekuitas dan per saham. Rasio laba bersih terhadap penjualan sebelum akuisisi menunjukkan tingkat profitabilitas yang kurang baik pada awalnya tetapi pada tahun 2001 rasio profitabilitas menunjukkan peningkatan yang baik sebesar 
161,77 \% dari 6,26\% di tahun 2000 menjadi 16,39\%. Pada tahun 2002 sesudah akuisisi, rasio ini menunjukkan angka 14,6 \% dimana rasio ini mengalami penurunan sebesar 10,92\% dari tahun sebelumnya. Di tahun 2003 rasio mengalami penurunan sebesar $14 \%$ menjadi 12,56\% walaupun perusahaan Pfizer memberikan kontribusi laba cukup besar yaitu sebesar 26,86 \% yaitu sekitar Rp 94,361 miliar. Hal ini disebabkan manajemen masih berusaha menyesuaikan diri dengan adanya akuisisi tersebut sehingga walaupun akuisisi telah dilakukan laba yang diperoleh belum terlalu besar untuk menaikkan margin ratio tersebut. Pada tahun 2004, rasio ini menunjukkan angka negative sebesar 19,24\%. Hal ini disebabkan pada tahun tersebut perusahaan harus menanggung kerugian yang sangat besar akibat selisih kurs yang terus labil.

Rasio pengembalian investasi sebelum dan sesudah akuisisi sangat berfluktuasi. Pada tahun sebelum akuisisi rasio ini menunjukkan angka yang cukup baik sebesar 20,45\% pada tahun 2001 . Tetapi pada tahun 2002 rasio ini mengalami penurunan menjadi 11,88\%. Pada tahun sesudah akuisisi rasio ini menunjukkan angka yang menurun terutama ditahun 2004 rasio ini mencapai angka negative sebesar $14,83 \%$. Hal ini menunjukkan penurunan sebesar $228,86 \%$ dari tahun sebelumnya Rasio pengembalian ekuitas menunjukkan rasio yang tidak baik sebelum akuisisi karena rasio ini terus menurun setiap tahun 1995 menjadi 24,55 \%. Hal ini berarti setiap Rp 1,00 ekuitas menghasilkan laba Rp 0,25. Pada tahun 2004 rasio ini mengalami penurunan derastis yaitu sebesar $365 \%$ karena kerugian yang diderita perusahaan.

Bardasarkan analisa rasio diatas, penulis akan menjabarkan hasil analisa tersebut agar dapat dilihat secara jelas pengaruh sebelum dan sesudah akuisisi bagi perusahaan induk yaitu PT Johnson \& Johnson. Berikut ini adalah hasil analisa yang dapat memperlihatkan kinerja perusahaan induk

Table 4.2

\section{Perbandingan Penilaian Rasio Keuangan Sebelum dan Sesudah Akuisisi}

\begin{tabular}{|c|c|c|}
\hline & \multicolumn{2}{|c|}{ P.T. Johnson \& Johnson } \\
\hline & Sebelum akuisisi & Sesudah akuisisi \\
\hline Rasio likuiditas & & \\
\hline Rasio lancar & Baik & Cukup Baik \\
\hline Rasio cepat & Baik & Cukup Baik \\
\hline Rasio Solvabilitas & & \\
\hline DAR & Cukup Baik & Kurang Baik \\
\hline DER & Cukup Baik & Tidak Baik \\
\hline EM & Cukup Baik & Kurang Baik \\
\hline Rasio Aktivitas & & \\
\hline Total Assets Tumover & Kurang Baik & Tidak Baik \\
\hline Inventory Tumover & Cukup Baik & Kurang Baik \\
\hline Rasio Profitabilitas & & \\
\hline Margin Ratio & Cukup Baik & Kurang Baik \\
\hline Retum on Investment & Cukup Baik & Kurang Baik \\
\hline Retum on Equity & Kurang Baik & Kurang Baik \\
\hline Eaming per Share & Baik & Kurang Baik \\
\hline
\end{tabular}

Sumber : PT. Johnson \& Johnson Indonesia

Berdasarkan tabel diatas dapat dilihat bahwa perusahaan induk mengalami penurunan kinerja. Rasio likuiditas mengalami penurunan tetapi masih dikategorikan cukup baik. Rasio solvabilitas membengkak menunjukkan bahwa rasio ini kurang baik karena hampir seluruh pembiayaan aktiva perusahaan menggunakan hutang. Rasio aktivitas terutama rasio perputaran aktiva menunjukkan angka yang terus menurun. Hal ini berarti dana yang tersimpan dalam aktiva tersebut hampir berputar dalam setahun dan bahkan membutuhkan waktu lebih dari satu tahun. Selain itu, rasio perputaran persediaan juga menunjukkan angka yang terus menurun. Ini berarti perusahaan melakukan penahanan stok persediaan. Rasio profitabilitas menurun sesudah akuisisi walaupun perusahaan yang 
diakuisisi memberikan kontribusi laba yang cukup besar, yaitu sebesar 18,58 \% pada tahun 2002 dan $26,86 \%$ pada tahun 2003. Hal ini dikarenakan manajemen kedua perusahaan sedang melakukan penyesuaian terhadap akuisisi tersebut.

\section{KESIMPULAN}

Berdasarkan hasil pembahasan yang mencerminkan suatu proses dimulainya dengan terpilihnya judul penelitian timbulnya masalah, tinjauan teori serta hasil analisa dan pembahasan terhadap transaksi akuisisi pada P.T Johnson \& Johnson, maka penulis berkesimpulan sebagai berikut

1. Akuisisi yang dilakukan adalah akuisisi finansial yang bertujuan untuk memperoleh keuntungan finansial dengan menguasai pangsa pasar dan menciptakan monopoli dipasar industri. Dengan demikian kegiatan usaha Johnson \& Johnson lebih terjamin karena konsumen akan membutuhkan obat - obatan yang dihasilkan oleh Pfizer.

2. Pelaksanaan akuisisi yang dilakukan oleh Johson \& Johnson terhadap Pfizer dilakukan setelah mendapat persetujuan RULBPS antara pihak - pihak yang berkepentingan, persetujuan dari Badan Koordinasi Penanaman Modal, persetujuan dari pihak lain seperti departemen kehakiman, dan pihak kreditor. Selain itu, Johson \& Johnson juga mengadakan penilaian terhadap perusahaan yang diakuisisi melalui pihak independen. Dengan demikian pelaksanaan akuisisi telah mengikuti aturan pemerintah sebagaimana yang telah diatur dalam UU No. 1 tahun 1995 tentang Perseroan Terbatas.

3. Metode penggabungan usaha yang dilakukan untuk akuisisi Johnson \& Johnson terhadap Pfizer adalah metode pembelian. Perlakuan akuntansi yang diterapkan adalah metode ekuitas karena Johnson \& Johnson mengakuisisi Pfizer dengan kepemilikan saham $100 \%$. Disini terlihat jelas bahwa Johnson \& Johnson mempunyai pengaruh signifikan dan mempunyai kendali terhadap Pfizer. Pembiayaan akuisisi tersebut menggunakan uang tunai dan hutang yang besarnya sama dengan nilai buku aktiva neto perusahaan sehingga tidak muncul goodwill. Perlakuan akuntansi untuk transaksi akuisisi tersebut telah sesuai dengan Pernyataan Standar Akuntasi Keuangan No. 22.

4. Perusahaan mengalami penurunan kinerja setelah perusahaan mengakuisisi Pfizer. Kesimpulan berdasarkan dari meningkatnya rasio solvabilitas yang tinggi. Karena perusahaan memiliki hutang yang cukup besar hamper seluruh pembiayaan perusahaan dibiayai ileh hutang. Hutang yang besar beresiko bagi perusahaan apabila terjadi kerisis ekonomi. Rasio aktivitas menunjukkan tingkat perputaran aktiva dan persediaan yang tidak baik. Dana yang tersimpan dalam aktiva hampir memerlukan waktu lebih dari setahun untuk kembali, sedangkan tingkat perputaran persediaan terus mengalami penurunan. Tingkat perputaran aktiva yang menurun menunjukkan bahwa perusahaan menahan stok persediaan. Hal ini mengakibatkan menigkatnay biaya - biaya yang terkait meliputi biaya penyimpanan,biaya asuransi, biaya kerusakan, dan lain-lain. Rasio profitabilitas terutama rasio laba terhadap penjualan menunjukkan penurunan sampai tahun 2004 walaupun perusahaan yang diakuisisi memberikan kontribusi laba yang cukup besar. Penurunan dari tahun 2002 ke tahun 2003 terjadi karena manajemen sedang menyesuaikan diri dengan akuisisi yang terjadi. Di tahun 2004 rasio ini mencapai angka negatif karena perusahaan mengalami kerugian dan menanggung beban bunga yang cukup besar

\section{Saran.}

1. Pihak perusahaan hendaknya memiliki pertimbangan alternative yang lebih baik untuk pendanaan akuisisi selain hutang. Apabila menggunakan hutang, sebaiknya hutang tersebut bukanlah hutang dalam mata uang asing untuk mencegah terdepresiasinya mata uang rupiah terhadap mata uang asing dan mencegah besarnya beban bunga yang ditanggung oleh perusahaan.

2. Pihak perusahaan sebaiknya melakukan evaluasi terhadap pelaksanaan akuisisi yang telah dilakukan yang meliputi kebijakan operasi perusahaan, manajemen, serta kebijakan keuangan karena perusahaan mengalami kinerja sejak tahun akuisisi terjadi. Pihak manajemen harus bersikap 
responsive dan lebih cepat mengadakan penyesuian-penyesuain antara kedua perusahaan agar kinerja perusahaan dapat lebih baik dimasa mendatang. Apabila setelah dilakukan evaluasi dan penyesuain yang perlu namun tidak terjadi peningkatan kinerja maka sebaiknya perusahaan meninjau kembali akuisisi tersebut atau bahkan mungkin melepas kembali kepemilikannya pada perusahaan yang telah diakuisisi

\section{DAFTAR PUSTAKA}

Ashari, D. dan. (2018). Pedoman Praktis Memahami Laporan Keuangan. Managerial Finance. Azizah. (2016). Hukum Perseroan Terbatas. Malang: Setara Press.

Aprilita, I., Tjandrakirana, R., \& Aspahani. (2013). Analisis Perbandingan Kinerja Keuangan Perusahaan Sebelum dan Sesudah Akuisisi (Studi Pada Perusahaan Pengakuisisi Yang Terdaftar di BEI Periode 2000-2011). Jurnal Manajemen dan Bisnis Sriwijaya Vol 11 No 2

Brigham, F, E., \& Houston. (2011). Dasar-dasar Manajemen Keuangan Terjemahan. Edisi 10. Jakarta: Selemba Empat.

Hamidah dan Noviani, Manasye. (2013). Perbandingan Kinerja Keuangan Perusahaan Sebelum dan Sesudah Merger dan Akuisisi (Pada Perusahaan Pengakuisisi yang Terdaftar di Bursa Efek Indonesia Periode 2004-2006). Jurnal Riset Manajemen Sains Indonesia (JRMSI), 4 (1), h:31-52

Hariyani, I., Serfianto, R., \& Yustisia, C. (2011). Merger, Konsolidasi, Akuisisi \& Pemisahan Perusahaan Cara Cerdas Mengembangkan \& Memajukan Perusahaan. Jakarta: Visimedia

Harahap, S. S. (2015). Analisis Krirtis Atas Laporan Keuangan. Edisi 1-10. Jakarta: PT.Raja Grasindo Persada.

Ikatan Akuntan Indonesia. (2016). Standar Akuntansi Keuangan- IAI Global. IAI Global, p. 1.3.

Kansil, C. S. T. K. dan C. S. T. (2005). Hukum Perusahaan Indonesia. Jakarta: Pradnya Paramita.

Kasmir. (2015). Pengertian Laporan Keuangan. Harahap (2015:105), 8(9), 1-58.

Kowanda, Dionysia. 2013. Merger dan Akuisisi. Bahan Kuliah Akuntansi Manajemen, Program Pasca Sarjana Universitas Gunadarma

Marcel, G. (2002). Akuisisi Bisnis, Analisis dan Pengelolaan. Jakarta: Penerbit Rineka Cipta.

Munawir. (2010). Analisa Laporan Keuangan Edisi 4. In Jakarta: Salemba Empat.

Novaliza, Putri dan Djajanti, Atik. (2013). Analisis Pengaruh Merger dan Akuisisi Terhadap Kinerja Perusahaan Publik di Indonesia. Jurnal Akuntansi \& Bisnis, 1 (1), h:1-16

Pernyataan Standar Akuntansi Keuangan (PSAK) Nomor 22 Tentang Akuntansi Penggabungan Usaha.

Resmilia, R., Hardiyanto, A. T., \& Ilmiyono, A. F. (2018). Pengaruh Merger dan Akuisis Terhadap Kinerja Keuangan Perusahaan Manufaktur Go Public yang Terdaftar di BEI Periode 2012-2014. Jurnal Online Mahasiswa Bidang Akuntansi, 5(5), 1-11.

Rodoni, dan A. (2014). Manajemen Keuangan Modern. Jakarta: Mitra Wacana Media.

Suryawathy, I Gusti Ary. (2014). Analisis Kinerja Keuangan Sebelum dan Sesudah Merger Pada Perusahaan yang Terdaftar di Bursa Efek Indonesia. Jurnal Ilmiah Akuntansi dan Humanika (JINAH) Universitas Pendidikan Ganesha, Vol.3, No.2 